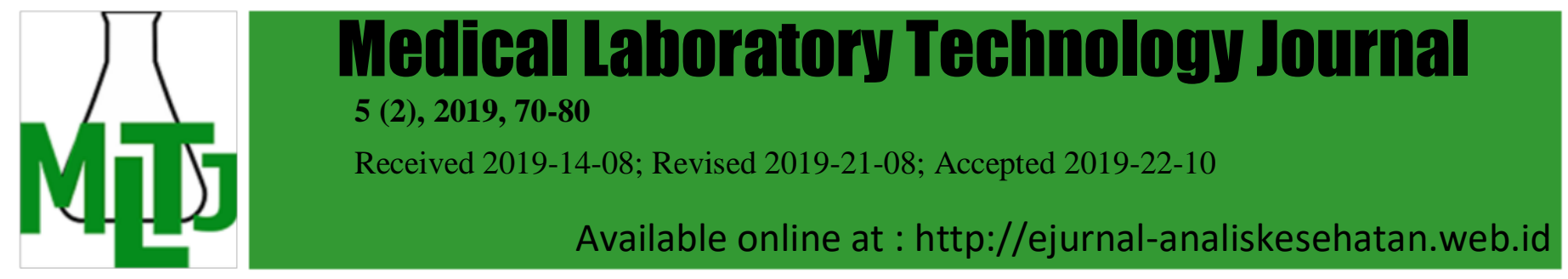

\title{
Anti-hyperglycemic Effect of Torbangun (Coleus amboinicus Lour) Leaves Extract Through Liver and Muscle Glycogen Deposits in Streptozotocin-induced Hyperglycmic Sprague-Dawley Rats Model
}

\author{
${ }^{\star}$ Meilla Dwi Andrestian ${ }^{1,2}$, Rizal Damanik ${ }^{2,3}$, Faisal Anwar ${ }^{2}$, Nancy Dewi Yuliana ${ }^{4}$ \\ ${ }^{1}$ Departement of Nutrition, Banjarmasin Health Polytechnic, Banjarbaru, South \\ Kalimantan, Indonesia $70714,{ }^{2}$ Department of Community Nutrition, Faculty of \\ Human Ecology, IPB University, Bogor, West Java Indonesia 16680, ${ }^{3}$ Southeast \\ Asian Food and Agricultural Science and Technology (SEAFAST) Center IPB \\ University, Bogor, West Java, Indonesia 16680, ${ }^{4}$ Department of Food Science, \\ Faculty of Agricultural Engineering and Technology IPB University, Bogor, West \\ Java, Indonesia 16680. Email: meilladwi74@gmail.com DOI: \\ $10.31964 / \mathrm{mltj} . v \%$ vi\%i.227
}

\begin{abstract}
The association of liver and muscle glycogen deposits with serum insulin levels, $\beta$-cells pancreas, and fasting blood glucose (FBG) of streptozotocin (STZ)induced hyperglycemic rats receiving Torbangun leaves extract (TE) investigated. The intervention performed on 25 8-week-old Sprague-Dawley rats divided into four groups. Seven rats separated as a normal group $(N)$, and other rats injected with streptozotocin (STZ). Confirmation of hyperglycemic was characterized by fasting blood glucose $>126 \mathrm{mg} / \mathrm{dl}$. Treatment group which is NG (hyperglycemic rats); N (normal rats); H-IM (62.5 mg/kg BW metformin); and H-IT (620 mg/kg BW TE) for 14 days. This study revealed that TE significantly decreased FBG levels, increased insulin production, and the amount of liver glycogen deposits $(a=0.01)$. However, the intervention did not significantly increase the amount of muscle glycogen deposits. TE administration improves $\beta$-cells, increases the liver and muscle glycogen deposits. TE was shown to have antihyperglycemic activity by improving the $\beta$-cell, increasing blood serum insulin levels, decreasing blood glucose levels, and increasing the liver glycogen deposits.
\end{abstract}

Keywords: diabetes; glycogen; hyperglycemia; torbangun (Coleus amboinicus Lour)

\section{INTRODUCTION}

Glycogen, which is the main carbohydrate deposit in the body, is mainly localized in the liver and skeletal muscle. It acts as a source of glucose when the body requires glycogen breakdown for energy metabolism, which referred to as glycogenolysis (Gropper and Smith, 2013).

The liver and muscle glycogen deposits of people with diabetes decrease because the glucagon activity increases with decreased insulin production, which is responsible for stimulating glycogen formation. Individuals with type 1 diabetes mellitus (DM) cannot adequately produce insulin. Meanwhile, individuals with type 2 DM can produce insulin in a fixed amount, but the insulin does not function properly (insulin resistance) because the insulin receptors in the cell membrane reduced or their structures altered. Thus, the receptors are unable to respond to the presence of insulin. This condition results in hyperglycemia because glucose cannot be stored in the form of glycogen, either in the liver or muscles.

Corresponding Author: Meilla Dwi Andrestian

Department of Community Nutrition, Faculty of Human Ecology,

IPB University, Kampus IPB Dramaga Bogor,West Java, Indonesia 16680

Email: meilladwi74@gmail.com 
Oral DM treatment can be performed by taking medications along with natural ingredients. Approximately 1,050 anti-DM plants have been studied (Subramoniam, 2016). One of the plant types used as a functional food and developed to control DM is Torbangun (Coleus amboinicus Lour). Torbangun leaves initially used for increasing breast milk production (galactagogue), which is a local belief of the people of North Sumatra, Indonesia. Lactating mothers in the Batak ethnic group in North Sumatra have a tradition of consuming Torbangun leaves after giving birth for increasing their breast milk production (Damanik et al., 2001; Damanik R, Wahlqvist ML, and Wattanapenpaiboon N, 2006; Damanik, 2009). Furthermore, the Torbangun plant has been widely used for its antibacterial and antifungal properties (Bhatt and Negi, 2012; Paul et al., 2014; Sabrina et al., 2014) and for controlling blood pressure, cholesterol levels (Suryowati et al., 2015a; Viswanathaswamy et al., 2011), and DM (Suryowati, 2015).

Torbangun leaves extract reportedly improves the function of pancreatic tissues, and it demonstrates insulinotropic effects (insulin production, secretion, and activity) (Viswanathaswamy et al., 2011). Torbangun (Coleus amboinicus Lour) leaves extract administered at a dose of $620 \mathrm{mg} / \mathrm{kg}$ body weight for 14 consecutive days has the potential to reduce blood glucose levels and free radicals, increase glucokinase and protect pancreatic $\beta$-cells of streptozotocin (STZ)-induced rats (Suryowati, 2015). STZ is generally used in rat models of diabetes (Kim et al., 2012).

The bioactive component of Torbangun leaves extract is the flavonoids (Suryowati et al., 2015b). One of them is quercetin, an antioxidant that plays a role in controlling blood glucose levels and can correct oxidative stress in diabetic rats (llagan et al. 2016; Lee et al. 2015). Quercetin can stimulate glucose uptake in the muscles through an insulin-independent mechanism involving adenosine monophosphate-activated protein kinase (AMPK). AMPK activation in the skeletal muscle increases glucose uptake through the stimulation of GLUT4 glucose transporter translocation to the plasma membrane. Meanwhile, in the liver, AMPK decreases glucose production primarily through the downregulation of the key enzymes of gluconeogenesis, namely, phosphoenolpyruvate carboxykinase and glucose-6-phosphatase (Eid et al., 2015).

This increased glucose uptake promotes glycogen formation (glycogenesis). Conversely, a decrease in gluconeogenesis allows the retention of glycogen deposits. So far, there is no known effect of Torbangun leaves extract on the mechanism of glycogen formation and its deposits when hyperglycemic occurs. Therefore, we aimed to evaluate the association of liver and muscle glycogen deposits of STZ-induced hyperglycemic rats receiving Torbangun leaves extract with serum insulin levels, $\beta$-cells pancreas, and blood glucose levels.

\section{MATERIALS AND METHOD}

This study used an experimental method with a completely randomized design (CRD) using Sprague-Dawley rats. The study was conducted from March 2017 to April 2018 at Bogor, West Java, Indonesia. The intervention divided into the following four groups: negative control ( $\mathrm{NG}$, six hyperglycemic rats); normal ( $\mathrm{N}$, six rats); control group ( $\mathrm{H}-\mathrm{IM}$, using $62.5 \mathrm{mg} / \mathrm{kg}$ body weight of metformin, six rats); and $\mathrm{H}$-IT (620 mg/kg body weight of Torbangun leaves extract, six rats). The dose of Torbangun leaves extract based on Suryowati et al. (2015a).

Torbangun leaves obtained from the gardens in the Cibeureum area, Bogor City (6o37'31.47" S, 106047'60.85" E), West Java, Indonesia, at an altitude of 298 m 
above sea level. The Torbangun seeds planted in a total area of $\pm 160 \mathrm{~m} 2$ with a spacing distance of $40 \mathrm{~cm}$ (Aziz, 2013). Torbangun leaves were harvested at the age of 8 weeks and picked approximately $15 \mathrm{~cm}$ from the plant shoot (Andarwulan et al., 2014). The Botanical Garden Conservation Center has authenticated plant samples, Indonesian Institute of Sciences, Bogor (Number B-2096/sIPH.3./KS/VII/2017). The experimental animals used were 25 8-week-old male Sprague-Dawley rats with a minimum weight of $140 \mathrm{~g}$ from PT. Indoanilab Bogor, West Java, Indonesia. The sample size was determined using Federer's formula. The research protocol implemented upon approval of Ethical Treatment No. 77-2017 from the Animal Ethics Commission, Institute for Research and Community Service, Bogor Agricultural University.

\section{Torbangun leaves extraction}

Torbangun leaves extraction followed the steps modified by (Suryowati et al., 2015b). The extraction was performed by sonication method using Powersonic 505 sonicator at $40 \mathrm{kHz}$ for $40 \mathrm{~min}$ at room temperature $\left(25^{\circ} \mathrm{C}\right)$, and the extract was then filtered (Annegowda et al., 2012). Solvent evaporation of the extract was performed using a rotary evaporator at $60^{\circ} \mathrm{C}$ (Viswanathaswamy et al., 2011). The rotary evaporator used was the Buchi RE-111. The thick extract obtained was stored at $4^{\circ} \mathrm{C}-8^{\circ} \mathrm{C}$ (Uma et al., 2011).

\section{Animal intervention}

We used Sprague-Dawley rats with a CRD. The intervention groups were NG (seven rats), $\mathrm{N}$ (six rats), H-IM (six rats), and H-IT (six rats). Except for the $\mathrm{N}$ group, the rats were given STZ induction with a dose of $40 \mathrm{mg} / \mathrm{kg}$ body weight (Jung et al., 2011) and hyperglycemic validated on day 3 when the fasting blood glucose (FBG) levels reached $>126 \mathrm{mg} / \mathrm{dl}$ (Akbarzadeh et al., 2007). Food and water were given ad libitum with 12/12 hours light/dark conditions (Kim et al., 2012). Torbangun leaves extract and metformin were both orally administered for 14 days for comparison. Data regarding FBG levels collected on days 0 , 4th, 7th, 11th, and 14th using a glucometer. Blood obtained through the tip of the tail (Kwon et al., 2013). Insulin levels measured from the blood serum and glycogen content measured from the rat liver and muscles that had necropsied on day 15 th.

\section{Necropsy}

All rats were administered general anesthesia with a combination of $90 \mathrm{mg}$ of ketamine and $10 \mathrm{mg}$ of xylazine. The necropsy performed by cutting through the skin and abdominal muscles until the abdominal cavity was open. Rat blood was removed until the heartbeat stopped, placed in a tube, and then centrifuged at 3000 rpm for $10 \mathrm{~min}$ (Rahmawati et al., 2014). A separate serum was obtained to measure insulin levels. The liver and soleus muscle samples collected for glycogen content measurement.

\section{Measurement of insulin levels}

Insulin levels were measured using the ELISA method (Salarinasab et al., 2017). The working procedure followed the manual of the ELISA kit (Cat. No E0707Ra) from the Bioassay Technology Laboratory, China. 


\section{Histopathological observation of the pancreas}

Pancreatic tissues were collected and fixed in $10 \%$ formalin neutral buffer solution, and the tissues then cut. Tissues were dehydrated using alcohol solution and were then infiltrated using paraffin xylene and vacuum dried. After that, tissues were cut using a microtome, and tissue slices were attached to the glass preparation. Objects were stained using hematoxylin and eosin dye before observation under a microscope (Slaoui and Fiette, 2011). The microscope used was Leica DM 750 Hiplan with an Optilab camera.

\section{Glycogen content measurement}

Glycogen content was measured using a spectrophotometric method (Sruthi et al., 2014). The spectrophotometer used was Genesys 20 Vis with I: 200-1100 nm. Liver and muscle organ preparation were initiated by isolating the organs in $15 \mathrm{ml}$ of $5 \%$ trichloroacetic acid solution in centrifuge tubes containing $5 \mathrm{ml}$ of ethanol, and the organs were stored overnight at room temperature. The tubes were then centrifuged at $3000 \mathrm{rpm}$ for $15 \mathrm{~min}$. The clear liquid formed the glycogen contained in the samples. The samples dissolved in $2 \mathrm{ml}$ of distilled water. A blank solution was made by preparing $2 \mathrm{ml}$ of distilled water into the centrifuge tubes. A standard solution prepared by adding $2 \mathrm{ml}$ of a glucose solution containing $0.1 \mathrm{mg}$ of glucose. Anthrone reagent added to all tubes, with $10 \mathrm{ml}$ for each tube. After the solution became homogenous, all tubes were soaked in a cold water bath until the temperature dropped. The tubes were then soaked in boiling water, soaked again in cold water, and cooled at room temperature. The solution transferred to a colorimetric tube, and its absorbance measured at a wavelength of $620 \mathrm{~nm}$. The following formula calculated the glycogen content:

\section{Glycogen content $=$ DU/DS $\times$ volume of the extract $\times 0.9 \times 0.1$}

\section{Tissue weight $(\mathbf{g})$}

Where DU is the optical density of the sample; DS indicates the standard optical density; 0.9 denotes the factor for converting the glucose value to glycogen value, and 0.1 is the amount of glucose in $2 \mathrm{ml}$ of the standard solution. The glycogen contained in the tissue was calculated and expressed in $\mathrm{mg}$ per $100 \mathrm{mg}$ of sample.

Data obtained from the results of the parameter the measurements were analyzed using paired sample T-test for FBG and analysis of variance for glycogen deposits at a $99 \%$ confidence interval. If there was a variance, the analysis continued with Tukey's honestly significant difference test.

\section{RESULTS AND DISCUSSION}

\section{Effects on fasting blood glucose levels}

Table 1 presents the effects of Torbangun leaves extract administration, which reportedly improves pancreatic tissue function and demonstrates insulinotropic effects (insulin production, secretion, and activity) in hyperglycemic rats. The high FBG levels in the STZ-induced groups at the beginning of intervention indicated that the study objects had hyperglycemia as one of the DM symptoms (>126 mg/dl). The FBG levels at the end of the study showed a decreased glucose level toward normal conditions. Meanwhile, the NG group was still hyperglycemic. Statistical analysis results revealed a significant difference between blood glucose levels at the beginning and end of the intervention in the $\mathrm{H}$-IM group $(p=0.002, \alpha=0.01)$ and $\mathrm{H}$-IT group $(p=0.005, \alpha=0.01)$.

Copyright @ 2019, MLTJ, ISSN 2461-0879 


\begin{tabular}{ccc}
\hline Groups & Initial glucose levels $(\mathrm{mg} / \mathrm{dl})$ & Final glucose levels $(\mathrm{mg} / \mathrm{dl})$ \\
\hline NG & $153.00 \pm 3.56$ & $167.33 \pm 14.58$ \\
N & $100.86 \pm 6.20$ & $91.29 \pm 8.24$ \\
H-IM & $147.83 \pm 6.84$ & $103.17 \pm 2.21^{\star \star}$ \\
H-IT & $155.83 \pm 9.56$ & $105.17 \pm 5.04^{\star *}$ \\
\hline
\end{tabular}

$\left.{ }^{\star *}\right)$ significant at $\alpha=0.01$

Cut off point FBG>126 mg/dl

$\mathrm{NG}=$ negative, $\mathrm{N}=$ normal, $\mathrm{H}-\mathrm{IM}=$ metformin drug control, $\mathrm{H}-\mathrm{IT}=$ Torbangun leaf extract intervention

The results of this study are following the results reported by Suryowati (2015), who intervened in extracts of Torbangun leaves extracted by the maceration method. Suryawati (2015) reported that Torbangun leaves extract at a dose of 620 $\mathrm{mg} / \mathrm{kg}$ BW can significantly reduce blood glucose levels through intervention for 14 days.

The maintenance of blood glucose concentration is an essential homeostatic function, and it is the primary function of the liver, skeletal muscles, and adipose tissues, representing the majority of the body tissues. This process is hormonally controlled, especially by hormones produced by the pancreas (i.e., insulin and glucagon) and glucocorticoid hormones produced by the adrenal cortex in the kidneys (Gropper and Smith, 2013). Insulin secreted by pancreatic $\beta$-cells and has a broad spectrum of anabolic effects in various tissues. In response to food intake, insulin stimulates the uptake and storage of carbohydrates, fat, and amino acids (Langlais et al., 2015). DM is a condition wherein the regulation of glucose homeostasis throughout the body is impaired, leading to various complications. Additionally, the ability of insulin to regulate glucose metabolism decreases (Henriksen, 2013).

Statistical analysis findings revealed a significant difference between blood glucose levels at the beginning and the end of the intervention in the H-IT group and showed the effectiveness of Torbangun leaves extract in reducing blood glucose levels in hyperglycemic rats.

\section{Effects on blood serum insulin levels}

An increase in blood glucose levels after carbohydrate consumption triggers insulin release and decreases glucagon secretion. Insulin is the only hormone that can stimulate a decrease in blood glucose levels, and it is a primary anabolic hormone. It stimulates the uptake of glucose, amino acids, and lipids. Next, it directs the conversion of these substances for storage in the muscles and adipose tissues (Gropper and Smith, 2013).

Table 2 presents the comparison of the blood serum insulin levels in rats receiving Torbangun leaves extract intervention and other interventions. Statistical analysis results revealed a significant difference between groups $(p=0.000, \alpha=0.01)$. The NG group showed the lowest insulin production and secretion compared with those in the other groups.

There was a significant increase in serum insulin production in the $\mathrm{H}$-IM and $\mathrm{H}-\mathrm{IT}$ groups. This shows an improvement in pancreatic cell- $\beta$ function by giving Torbangun leaves extract almost as effective as metformin. The study conducted by Ismail et al. (2015) reported that metformin plays a role in improving pancreatic cell- 
$\beta$, increasing insulin expression. In addition to increasing serum insulin levels, Cheng et al. (2006) also reported that metformin was able to improve insulin receptors, which led to improvements in GLUT4 gene expression and decreased expression of PEPCK genes. Bösenberg and Zyl (2008), metformin can increase insulin sensitivity, thereby reducing gluconeogenesis and glycogenolysis. Besides, metformin also increases GLUT-4 and GLUT-1 regulation to increase glucose storage.

The pathogenesis of DM is characterized by a metabolic disorder, that is, a decrease in peripheral tissue response to insulin (Kangralkar et al., 2010). The damage in the peripheral tissue occurs due to an increase in free radicals in the body. According to Viswanathaswamy et al., a decrease in blood glucose levels in rats that administered Torbangun leaves extract occurred through the restoration of pancreatic tissue function and insulinotropic effects (Viswanathaswamy et al., 2011). This occurs because the antioxidants present in the Torbangun leaves extract can capture the free radicals that formed as a result of hyperglycemia. The decreased levels of free radicals caused the insulin receptors to function properly; thus, glucose could be transported into cells, resulting in glycogenesis and decreased gluconeogenesis.

Table 2. Profile of Rats' Blood Serum İnsulin Levels

\begin{tabular}{cc}
\hline Groups & Insulin levels $(\mathrm{IU} / \mathrm{I})$ \\
\hline NG & $7.33 \pm 0.40$ \\
$\mathrm{~N}$ & $9.31 \pm 0.99$ \\
H-IM & $12.87 \pm 1.25^{\text {** }}$ \\
H-IT & $13.67 \pm 0.51^{\text {** }}$
\end{tabular}

${ }^{\star *}$ ) significant at $\alpha=0.01$

$\mathrm{NG}=$ negative, $\mathrm{N}=$ normal, $\mathrm{H}-\mathrm{IM}=$ metformin drug control, $\mathrm{H}-\mathrm{IT}=$ Torbangun leaves extract intervention

Torbangun leaves extract contains flavonoid compounds, with potential antioxidant effects (Patel et al., 2010). Flavonoids are frequently found in plants and are involved in a-glucosidase inhibition (Lee et al., 2015). The flavonoids contained in the Torbangun leaves extract can inhibit enzymes, resulting in a decrease in carbohydrate hydrolysis and glucose absorption (Suryowati, 2015). Furthermore, it assumed that the flavonoid that plays a role is quercetin. Quercetin can decrease oxidative stress in diabetic rats (Lee et al., 2015; Suryowati et al., 2015b), and quercetin also a powerful antioxidant that directly catches reactive oxygen species and activates antioxidant enzyme functions (Jeong et al., 2012). However, based on studies conducted on the role of antioxidants in DM recovery, the antihyperglycemic potential in plant extracts is related to one type of flavonoids or the synergistic effects of various flavonoids contained (Jung et al. 2011).

\section{Histopathological observation of the pancreas}

Figure 1 presents the results of histopathological observations in all treatments with 400 times enlargement. The results revealed that the NG group had decreased the number and size of $\beta$-cells and decreased the size of islets of Langerhans. Islets of Langerhans in group $N$ appeared normal, $\beta$-cells were in the direction of the medulla with a precise hexagonal shape, whereas $\alpha$-cells were in the cortical part of the islets of Langerhans. The $\mathrm{H}$-IM group showed normal pancreatic conditions with Langerhans Island, and although $\beta$ cells and $\alpha$-cells were difficult to 
distinguish, there was a residual bent toward $\beta$-cells. The $\mathrm{H}$-IT group still showed $\alpha$ cell dominance, but the $\beta$-cells repair was detected.

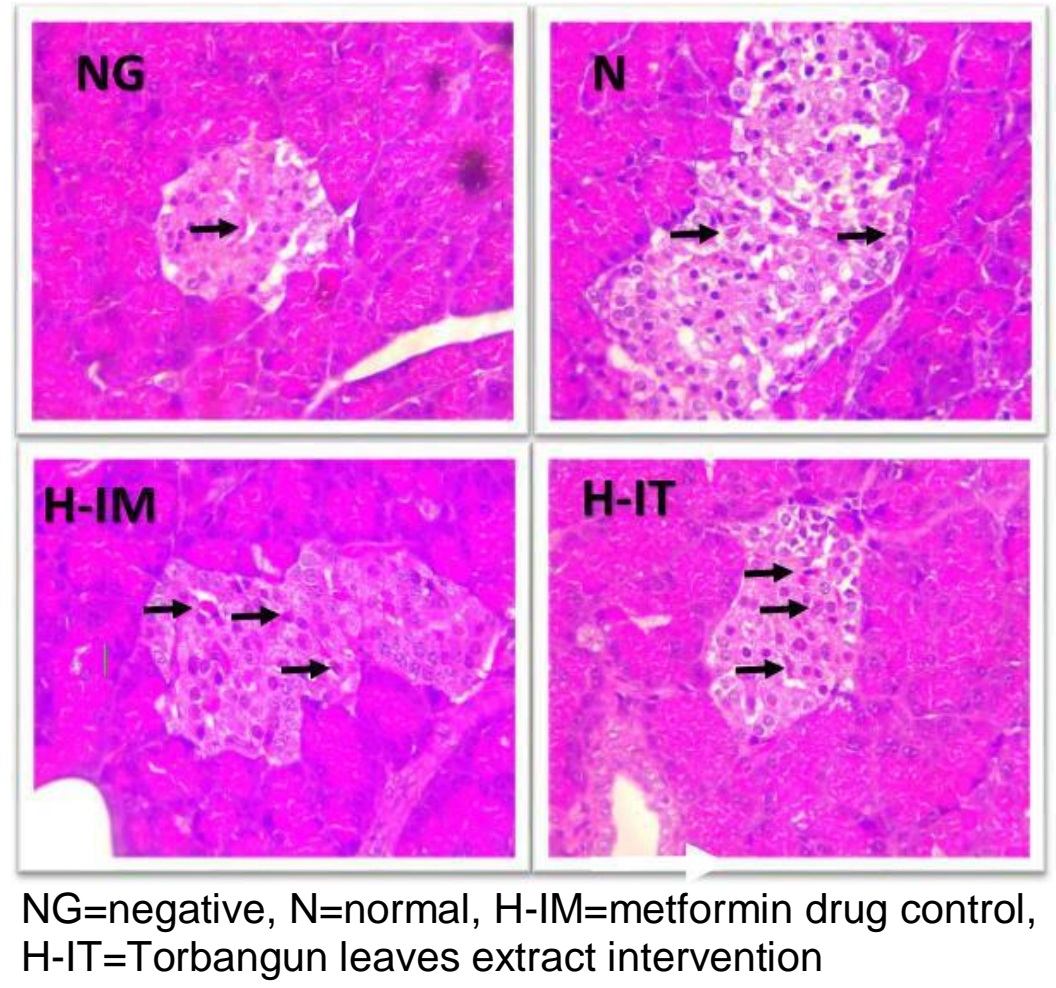

Figure 1. Rats' Pancreatic Histology In All Groups That Showed Langerhans Island and $\beta$-Cells Indicated by Arrows

This is in line with the study conducted by Suryowati (2015), who reported changes in $\beta$-pancreatic cells by treating Torbangun leaves extract resulting from maceration extraction. Changes occur because endocrine cells begin to regenerate towards normal forms, although there are still some endocrine cells that degenerated.

The increase in serum insulin levels of $\mathrm{H}$-IM and $\mathrm{H}$-IT groups indicated an improvement in pancreatic $\beta$-cells that had previously been damaged by STZ induction. The liver of diabetic rats receiving Torbangun leaves extracts had regeneration changes to normal conditions (Suryowati, 2015). Torbangun leaves extract administration protected endocrine cells so that insulin secretion can be increased.

\section{Liver and muscle glycogen deposits}

The profile of insulin production also manifested in the rat glycogen deposits in all intervention groups. The $\mathrm{H}$-IT group with the highest insulin content also showed the most glycogen deposits than other groups, either in the liver or muscles. Glycogen deposits, especially in the liver, showed a significant difference $(p=0.000$, $\alpha=0.01$ ) (Table 3). 
Table 3. Rats' Glycogen Deposits at The End of The İntervention

\begin{tabular}{ccc}
\hline Groups & Liver glycogen deposit $(\mathrm{mg} / \mathrm{g})$ & Muscle glycogen deposit $(\mathrm{mg} / \mathrm{g})$ \\
\hline $\mathrm{NG}$ & $5.65 \pm 1.02$ & $2.91 \pm 0.70$ \\
$\mathrm{~N}$ & $7.02 \pm 1.78$ & $3.36 \pm 0.89$ \\
$\mathrm{H}-\mathrm{IM}$ & $7.21 \pm 1.74$ & $3.67 \pm 0.83$ \\
H-IT & $10.65 \pm 0.54^{\star *}$ & $3.71 \pm 0.73$ \\
\hline
\end{tabular}

$\left.{ }^{* *}\right)$ significant at $\alpha=0.01(\mathrm{p}=0.000)$

$\mathrm{NG}=$ negative, $\mathrm{N}=$ normal, $\mathrm{H}-\mathrm{IM}=$ metformin drug control, $\mathrm{H}-\mathrm{IT}=$ Torbangun leaves extract intervention

The glycogen deposits in the liver comprise $7 \%$ of the liver weight, while the glycogen deposits in the muscles comprise only $1 \%$ of all skeletal muscles. Although the relative concentration of glycogen in the liver is higher than in the muscles, the highest total glycogen deposit in the body is in the skeletal muscles (Gropper and Smith, 2013).

The liver plays a vital role as a guardian of postprandial hyperglycemia through glycogen synthesis. DM is a result of the failure of the liver in performing glycogenesis. In STZ-induced rats, DM occurs because of the deactivation of enzyme glycogen synthase phosphatase (Suarsana et al., 2010). The number of glycogen deposits in individuals with DM decreases because of reduced insulin production or sensitivity; thus, glycogenesis inhibited, and glycogenolysis occurs in the liver, which contributes to an increase in blood glucose levels. Therefore, DM therapy is expected to increase insulin production so that glycogenesis occurs properly, and glycogenolysis can be inhibited to attain glucose homeostasis in the body.

The profile of insulin production also manifested in rat glycogen deposits in all intervention groups. The H-IT groups that had the highest insulin content also showed the most glycogen deposits compared with other groups, either in the liver or muscles. The liver glycogen deposits in the H-IT group even showed a significant difference compared with the liver glycogen deposits of other groups. This is because the glycogen deposits in the liver directly contributed to blood glucose levels.

Increased insulin production in the $\mathrm{H}$-IM and $\mathrm{H}$-IT groups also tends to increase muscle glycogen storage. This occurs because insulin can stimulate an increase in GLUT4 transporter activity, which plays a role in glucose translocation from the blood to muscle cells (Jung et al., 2017). Unlike the glycogen deposits in the liver, glycogen deposits in the muscles are a source of energy used by the muscles themselves and do not directly contribute to blood glucose levels (Gropper and Smith, 2013). Thus, DM therapy, through either medications or Torbangun leaves extract, did not provide a significant difference in muscle glycogen deposits.

Diabetic rats that provided tempeh extract intervention showed an increase in glycogen deposits in the liver or muscles (Jeong et al., 2012). An increase in glycogen deposits was also detected in diabetic rats receiving NIDDWIN (formulation of 11 types of anti-DM herbs) therapy. This occurred because of an increase in the conversion of blood glucose to glycogen. The decreased blood glucose levels could be associated with the anti-DM activity of those herbal mixtures (Sruthi et al., 2014). Likewise, the case in hyperglycemic rats administered Torbangun leaves extract. There was a decrease in glucose levels in line with the increase in insulin levels and glycogen deposits, especially in the liver. This indicates that the Torbangun leaves 
extract at dose $620 \mathrm{mg} / \mathrm{BW}$ can hasten glycogenesis, and its effectiveness is nearly similar to metformin and several other types of anti-DM herbal therapy.

\section{CONCLUSION}

The administration of Torbangun extract to rats increases the liver and muscle glycogen deposits. These increased deposits in the liver and muscles are in line with increased blood serum insulin levels and decreased blood glucose levels. Therefore, it can conclude that Torbangun leaves extract to have antihyperglycemic activity by improving the $\beta$-cell, increasing blood serum insulin levels, decreasing blood glucose levels, and increasing the liver glycogen deposits.

\section{ACKNOWLEDGMENTS}

This research partly supported by a grant from Directorate of Research and Community Service Directorate General of Research and Development Strengthening, Ministry of Research, Technology and Higher Education, the Republic of Indonesia for supporting our research with a partial grant and the experimental system.

\section{REFERENCES}

Akbarzadeh, A., Norouzian, D., Mehrabi, M.R., Jamshidi, S., Farhangi, A., Verdi, A.A. (2007). Induction of diabetes by streptozotocin in rats. Indian Journal of Clinical Biochemistry, 22(2), 60-64.

Andarwulan, N., Yuliana, N.D., Hasna E, Aziz S.A., Davis, T.D. (2014). Comparative analysis of three torbangun clones (Plectranthus amboinicus (Lour.) Spreng) based on phenotypic characteristics and phenolic content. American Journal of Plant Science, 5(5), 3673-3683.

Annegowda, H.V., Bhat, R., and Min-tze, L. (2012). Influence of sonication treatments and extraction solvents on the phenolics and antioxidants in star fruits. Journal of. Food Science and Technlogy, 49(4), 510-514.

Aziz, S. 2013. Standards operational procedures for Bangun-Bangun cultivation. Bogor, Indonesia: SEAFAST Center, Bogor Agricultural University: 7-16.

Bhatt, P., Negi, P. (2012). Antioxidant and antibacterial activities in the leaf extracts of Indian Borage (Plectranthus amboinicus). Food and Nutrition Science, 3(2), 146-152.

Bösenberg, L., Zyl, D. 2008. The mechanism of action of oral antidiabetic drugs: A review of recent literature. Journal of Endocrinology, Metabolism and Diabetes of South Africa, 13(3), 80-88.

Cheng, J.T., Huang, C.C., Liu, I.M., Tzeng T.F., Chang, C.J. 2006. Novel mechanism for plasma glucose-lowering action of metformin in streptozotocin-induced diabetic rats. Diabetes, 55(3), 819-825.

Damanik, R. (2009): Torbangun (Coleus amboinicus Lour). A bataknese traditional cuisine perceived as lactagogue by Bataknese lactating women in Simalungun, North Sumatera, Indonesia. Journal of Human Lactation, 25(1), 64-72.

Damanik R., Damanik N., Daulay Z., Saragih S., Premier R., Wattanapenpaiboon N., Wahlqvist N. (2001). Consumption of Bangun-bangun leaves (Coleus amboinicus Lour) to increase breast milk production among Batakneese women in North Sumatra Island, Indonesia. Asia Pacific Journal of Clinical Nutrition, 10(4), S67.

Damanik, R., Kustiyah, L., Hanafi, M., Iwansyah, A.C. (2017). Evaluation lactogenic activity of ethyl acetate fraction of Torbangun (Coleus amboinicus L.) leaves. In 
IOP Conference Series Earth and Environmental Science (pp. 1-10). IOP Publishing.

Damanik, R., Wahlqvist, M.L., Wattanapenpaiboon, N. (2006). Lactagogue effects of Torbangun, a Bataknese traditional cuisine. Asia Pacific Journal of Clinical Nutrition, 15(2), 267-274.

Eid, H., Nachar, A., Thong, F., Sweeney, G., Haddad, P.S. (2015). The molecular basis of the antidiabetic action of quercetin in cultured skeletal muscle cells and hepatocytes. Pharmacognosy Magazine, 11(41), 74-82.

Gropper, S.S., Smith, J. (2013): Advance nutrition and human metabolism. Belmonlt USA, Yolanda Cossio.

Henriksen, J. (2013). Role of oxidative stress in the pathogenesis of insulin resistance and type 2 diabetes. In Watson R.R. \& Preedy V.R. (eds). Bioactive Food as Dietary Interventions for Diabetes, San Siego, Academic Press.

llagan, J.R., Hurtada, W.A., Barrion, A.S.A., Estacio, M.A.C., Dizon, E. (2016). Glucose lowering effect of horseradish tree (Moringa oleifera Lam.) leaf decoction in alloxan-induced diabetic mice. Malaysia Journal of Nutrition, 22(2), 267-278.

Ismail, T.A., Soliman, M.M., Nassan, M.A. 2015. Molecular and immunohistochemical effects of metformin in a rat model of type 2 diabetes mellitus. Experimental and Therapeutic Medicine. 9(5), 1921-1930.

Jeong, S., Kang, M., Choi, H., Kim, J., Kim, J. (2012). Quercetin ameliorates hyperglycemia and dyslipidemia and improves antioxidant status in type 2 diabetic db/db mice. Nutrition Research and Practice, 6(3), 201-207.

Jung, H., Kim, Y.Y., Kim, B., Nam, H., Suh, J.G. (2017). Biochemical and biophysical research communications improving glycemic control in model mice with type 2 diabetes by increasing superoxide dismutase (SOD) activity using silk fibroin hydrolysate ( SFH ). Biochemical and Biophysical Research Communications, 493(1), 1-5.

Jung, J.Y., Lim, Y., Moon, M.S., Kim, J.Y., Kwon, O. (2011). Onion peel extracts ameliorate hyperglycemia and insulin resistance in high fat diet/streptozotocininduced diabetic rats. Nutrition and Metabolism, 8(18), 1-8.

Kangralkar, V.A., Patil, S.D., Bandivadekar, R.M. (2010). Oxidative stress and diabetes: a review. International Journal of Pharmaceutical Application, 1(1), 38-45.

Kim, J., Kim, H., Lee, S. (2012). Hyperglycemic effect of submerged culture extract of Ceriporia lacerata in Streptozotocin-induced diabetic rats. Food Science and Biotechnology. 21(6), 1685-1693.

Kwon, S., Im, J., Jeon, S., Jee, H., Park, Y., Lee, H., Kim, D. and Lee, Y. (2013). Antihyperglycemic effect of fermented gastrodia elata blume in streptozotocininduced diabetic mice. Food Science and Biotechnology, 22(5), 1403-1408.

Langlais, P.R., Mandalino, L.J., Garvey, W.T. (2015). Mechanisms of insulin signal transduction. pp. 163-192. In DeFronzo, R.A., FRerrannini, E., Zimmet, P., Alberti, K.G.M.M. (eds). International Textbook of Diabetes Mellitus. JohnWiley \& Sons Ltd, West Sussex, UK.

Lee A., Kang M., Choe E., Kim J. (2015). Hypoglycemic and antioxidant effects of Daraesoon (Actinidia arguta Shoot) in animal models of diabetes mellitus. Nutrition Research and Practice, 9(3), 262-267.

Patel, R.D., Mahobia, N.K., Singh, A., Singh, M.P., Sheikh, N.W., Gulzar, A., Singh, S.K. (2010). Antioxidant potential of leaves of Plectranthus amboinicus (Lour) Spreng. Der Pharmacia Lettre, 2(4), 240-245. 
Paul, N.M., Mohan, A., John, E., John, N., Ajitha, A.R., Avirah, S.A. (2014). Phytochemical screening and evaluation of the antimicrobial potential of Coleus amboinicus. World Journal of Pharmaceutical Research. 3(2), 2811-2826.

Rahmawati, G., Farida, R.N., Winarsi, H. (2014). Aktivitas superoksida dismutase tikus diabetes yang diberi ekstrak batang kapulaga dan glibenklamid. Scripta Biologica, 1(3), 197-201.

Sabrina, E.M., Ahs, M., Shukri, M.M. (2014). Antimicrobial activity and bioactive evaluation of Plectranthus amboinicus essential oil. American Journal of Research Communication. 2(12),121-127.

Salarinasab, S., Nourazarian, A., Nikanfar, M., Abdyazdani, N., Kazemi, M., Feizy, N., Rahbarghazi, R. (2017). Impact of morphine on the expression of insulin receptor and protein levels of insulin/IGFs in rat neural stem cells. Neuroscience Letter, 660(1),147-154.

Slaoui, M., Fiette, L. Histopathology procedures: from tissue sampling to histopatholoical evaluation. (2011) In Clifton, N.J (ed). Drug Safety Evaluation: Methods and Protocols, Methods in Molecular Biology (pp. 69-82). Springer Science, LLC. .

Sruthi, T., Satyavati, D., Reddy, C.M., Srilatha, N. (2014). Estimation of glycogen content in liver, skeletal muscle and cardiac muscle of NIDDWIN, a polyherbal formulation in alloxan induced diabetic rats. Journal of Pharmaceutical Innovation, 2(12), 56-60.

Suarsana, I.N., Priosoeryanto, B.P., Wresdiyati, T. (2010). Synthesis of liver and muscle glycogen in diabetic rats given tempe extract. Jurnal Veteriner. 11(3), 190-195.

Subramoniam, A. (2017). Anti-diabetes mellitus plants: active principles, mechanisms of action and suistainable utilization. London, UK, CRC Press.

Suryowati, T. (2015): Efficacy of Torbangun (Coleus amboinicus Lour) on oxidative stress diabetic rats. (Doctoral dissertation), IPB University, Bogor.

Suryowati, T., Rimbawan, Damanik, R., Bintang, M., Handharyani, E. (2015a). Identifikasi komponen kimia dan aktivitas antioksidan dalam tanaman Torbangun (Coleus amboinicus Lour). Jurnal Gizi dan Pangan, 10(3), 217-224.

Suryowati, T., Rimbawan, Damanik, R., Bintang, M., Handharyani, E. (2015b). Antihyperlipidemic activity of Torbangun extract (Coleus amboinicus Lour) on diabetic rats induced by streptozotocin. IOSR Journal of Pharmacy, 5(5), 50-54.

Uma, M., Jothinayaki, S., Kumaravel, S., Kalaiselvi, P. (2011). Determination of bioactive components of Plectranthus amboinicus Lour by GC-MS analysis. New York Science Journal, 4(8), 66-69.

Viswanathaswamy, A., Koti, B., Gore, A., Thippeswamy, A., Kulkarni, R. (2011). Antihyperglycemic and antihyperlipidemic activity of Plectranthus amboinicus on normal and alloxan-Induced diabetic rats. Indian Journal of Pharmaceutical Science, 73(2), 139-145. 